\title{
anemon
}

Muş Alparslan Üniversitesi Sosyal Bilimler Dergisi

ISSN: 2147-7655

Cilt:3 Sayı:1 Haziran: 2015

THE ACCULTURATION MODEL IN SLA: REVIEW AND DISCUSSION

\section{Eda YUCA*}

\begin{abstract}
The role of language and culture in society has been the concern of not only linguists, anthropologists and communication scholars but also of the researchers in sociology, psychology, cognitive science and education. This relationship has been investigated from different perspectives depending on the focus of the authorities. The research on second language acquisition has dealt with this relationship by generating various theories, models, approaches and principles depending on the nature of language and culture relationship. One of these models is Schumann's Acculturation Model (1978) for second language acquisition. This paper aims to review, evaluate and critically discuss The Acculturation Model in the light of supporting or opposing empirical evidence. Initially referring culture and language relationship, the paper evaluates the Acculturation Model after the review of the model with the main principles and arguments.
\end{abstract}

Key Words: Second Language, Culture, Acculturation, Social Distance

\section{İKINCI DİL EDİNIMINDE KÜLTÜREL ETKILEŞIM MODELI: IINCELEME VE TARTIŞMA}

\section{Özet}

Dil ve kültürün toplum içindeki rolü sadece dil bilimciler, antropologlar ve iletişim bilimcilerin değil sosyologlar, bilişimciler ve eğitimcilerin de ilgi alanı olmuştur. Dil ve kültür ilişkisi çeşitli disiplinler tarafından odak noktalarına bağlı olarak farklı bakış açılarıyla ele alınıp incelenmiştir. İkinci dil edinimi alanındaki çalışmalar dil ve kültür arasındaki ilişkinin doğasını incelerken çeşitli teoriler, modeller, yaklaşımlar ve ilkelerin oluşmasına katkı sağlamıştır. Bu bağlamda oluşturulmuş modellerden biri Schumann'ın (1978) ikinci dil ediniminde Kültürel Etkileşim Modeli'dir. Bu çalışma deneysel bulgular 1şı̆̆ı̆nda Kültürel Etkileşim Modeli'ni incelemeyi, değerlendirmeyi ve eleştirel bir bakış açısıyla tartışmayı amaçlamaktadır. Bu çalışmada öncelikle dil ve kültür ilişkisine değinilmiş, Kültürel Etkileşim Modeli'nin ana ilkeleri ve varsayımları incelenmiş ve son olarak da bu modelin kritiği yapılmıştır.

Anahtar Sözcükler: İkinci Dil, Kültür, Kültürel Etkileşim, Sosyal Mesafe

\footnotetext{
* Arş. Gör. Muş Alparslan Üniversitesi, Eğitim Fakültesi, Yabancı Diller Eğitim Bölümü, İngiliz Dili ve Eğitimi,
} e-mail: e.yuca@alparslan.edu.tr 


\section{Introduction}

For many years authorities have attempted to explore the relationship between language and culture from different perspectives. To comprehend this relationship, it is crucial to investigate how culture has been defined and conceived by various scholars so far and what is meant by language. Though it is not easy to define culture, culture has often been understood as a body of acquired and shared by a group of people for generations through individual and group striving. This body of knowledge includes knowledge of beliefs, values, attitudes, religion, events, symbols, and ways of living, works of art, places and cultural artefacts. According to Peck (1998) culture is all the accepted ways of behavior of a certain society which are learned in the consequence of belonging to some particular group. As an inherent part of humankind, culture acts as a means by which knowledge, values, norms and experience are transmitted onto next generations. Mistrik (1999) emphasizes the role of culture in the development of human kind as an inevitable, conscious and unconscious process. On the other hand, culture has been viewed by Crozet and Liddicoat (2000) as a dynamic process which is open to change through contact with other cultures.

Culture provides individuals with a particular way of living and body of knowledge through which they find a place for themselves in social time and space, and communicate and participate in the rituals of social life. As social beings sharing a certain culture, people use language to maintain and convey their cultural features and ties from one generation to the next since language, a social practice is a system of tools in the construction of social life. It can be said that culture is majorly experienced through language. Therefore, language plays a crucial role in establishing and maintaining culture. Within a cultural framework, meaning is created and interpreted through language. This relationship is not one directional which means it is not just language that shape culture but it is also shaped by culture. Samovar, Porter and Jain (1981) explain that culture and communication is integrated since culture both determines who talks to whom, about what and how the communication continues and also helps to identify how messages and meanings are encoded by individuals, and conditions and circumstances under which various messages may or may not be conveyed, interpreted or noticed. In this respect culture is the foundation of communication that is culture shapes language.

As it is asserted by Brown (2007), culture is deeply ingrained within us, and language is the most visible and available expression of it. To accomplish a deeper understanding of culture and language relationship, the differences between two cultures in the use of a language can be investigated. For instance, Howell \& Vetter (1976) found out that when an American sees a bus coming, he generally uses the present progressive "the bus is coming" however, Japanese uses the present perfect "the bus has come". Culture seems 
to have its own grammar that imposes itself upon language use and makes people of a certain culture conceptually organize experience in a more different way than those of another culture.. Culture and language seem to be intertwined in a complex relationship and they are inseparable. But, what happens to people when they move from the culture they have been born and raised to a new and foreign culture?

When various people from different cultural backgrounds meet each other, they probably will adapt or will not adapt to each other's behaviors, lifestyles, languages, beliefs, values, social institutions, traditions, and technologies. However, to what extent and how this adaptation and change occurs within people's lives is not easy to answer. Also how well individuals manage that change and the consequences of this process is not straight forward. The issues originating from these questions have been referred as 'acculturation' which comprises "those phenomena which result when groups of individuals having different cultures come into continuous first-hand contact with subsequent changes in the original culture patterns of either or both groups" by Redfield and et al. (1936, cited in Navas et al., 2005).

The complex interaction of cultural, social, linguistic and individual factors associated with migration and settling in another country led to the creation of different multidimensional models of acculturation (Cabassa, 2003). Among all of the models of acculturation, the present paper's focus will be on Schumann's Acculturation Model (1978) which examines the acquisition process of a second language by members of ethnic minorities. Developed from Schumann's observation of uninstructed acquisition of English by Alberto, a 33-year-old, working class Costa Rican living in Boston, this model emphasizes the relationship between language learner and target language community. This paper aims to review and critically discuss the Acculturation Model in terms of second language acquisition with a view to the relationship between language and culture.

\section{The Acculturation Model}

The model was developed to explain the acquisition of an L2 by immigrants in majority language settings based on social and psychological factors. Acculturation is defined via the social and psychological taxonomy of factors which are supposed to be major cause of SLA process (Schumann, 1978). Differences in learner's development rate and level of ultimate achievement are explained with regard to the extent to which learners adapt to the culture of target language group by this model. Schumann claims that a learner's success in second language acquisition is dependent on the amount of acculturation as he mentions:

"...second language acquisition is just one aspect of acculturation and the degree to which a learner acculturates to the target language group will control the degree to which he acquires the second language" (Schumann, 1978: 34). 
According to Schumann (1986) there exist two kinds of acculturation in terms of the learner's view of the target language group. Both types of acculturation lead to social integration; however, in the first type of acculturation individuals are fairly willing to get integrated in the target language culture while in the second type they do not. It is argued by Schumann that L2 acquisition is efficiently realized through both types of acculturation.

In addition to the two types of acculturation, two main factors (social and psychological) are effective in Schumann's model to account for differences in the way language learners acquire language. These factors determine the levels of social distance and psychological distance (Schumann, 1978). Social distance refers to the level of which a language learner as a member of a social group becomes a member of the target language group in contact. Schumann enlists eight factors that control social distance:

Social dominance: If the first language group is politically, culturally, economically or technically superior or inferior to the target language group, social contact between these groups may not be adequate for the target language acquisition. If the status of both groups is nearly equal, then the contact between them will increase and thus, the acquisition of the target language will be promoted.

Integration pattern: The L1 group may assimilate by adopting the lifestyles and values of target language group, preserve its own lifestyles and values or adopt those of target language group while maintaining its own for intra-group interaction. When L1 group wants to assimilate into target language group, it is considered the best for the acquisition of the second language. But if the L1 group wants to remain separated linguistically and culturally from the target language group, then the target language will be acquired in the least favorable conditions.

Enclosure: The more the L1 group shares the same social facilities like schools, churches, workplaces, clubs, etc. with the target language group, the more suitable conditions will be for the target language acquisition.

Cohesiveness: If the L1 group is cohesive in terms of intra-group contacts, it will tend to remain separate from the target language group and thus less target language acquisition will occur.

Size: The smaller the L1 group, the more likely the contact with the target language group and the more suitable conditions for L2 acquisition.

Cultural congruence: If the two cultures are similar, social contact is more likely and $\mathrm{L} 2$ acquisition is more facilitated.

Attitude: The more positive the views of the L1 group toward the target language 
group, the more likely there will be social contact and language acquisition.

Intended length of residence: The longer the L1 group plans to remain in the target language environment, the more necessity they will feel to acquire the second language.

Apart from social factors, there are four psychological variables that affect psychological distance included in Schumann's model. Psychological distance concerns how comfortable a learner is in relation to the surrounding social factors. The variables affecting psychological distance are as follows:

Language shock: The degree to which L2 learners are afraid of looking comic when using L2.

Culture shock: The degree to which L2 learners feel disoriented as a result of cultural differences.

Motivation: The degree to which L2 learners are integratively or instrumentally motivated to acquire L2.

A learner with integrative motivation wants to acquire the target language in order to communicate with the members of that language while one with instrumental motivation is interested in the acquisition of second language for more self-oriented reasons such as gaining more career opportunities or earning more money. Thus motivated learners either integratively or instrumentally experience minimal psychological distance.

Ego permeability: The degree to which L2 learners give up their differences in favor of the target language group.

With the cluster of social-psychological factors, Schumann asserts that any learner can be placed along a continuum ranging from social-psychological distance to social-psychological proximity with the target language group. The degree of language acquisition is associated with the degree of learner's proximity and contact to target group. Therefore, the greater the contact, the more acquisition takes place. It can be said that the degree to which an L2 learner is successful in SLA depends on to some extent and how much contact the learner has with the target language speakers (Schumann, 1986).

\section{Discussion}

Language and culture are linked in the transmission of knowledge, in the construction of social life and ideologies about the use of language and its relation to human behavior. There is a fundamental, interdependent, inseparable and inextricable relationship between language and culture since it is language that creates meaning in its cultural context. To better figure out, create and share meanings and to eliminate misunderstandings, culture should be taken into account in second language acquisition process especially when an individual begins to live in another culture with different language. The language envi- 
ronment has an undeniable major effect on an individual's language acquisition process. Highlighting this influence accompanied by other related factors, Schumann accomplished to indicate another significant perspective taking social and psychological distance into account in second language acquisition research.

There have been relatively few empirical studies supporting the Acculturation Model though. Among the evidence supporting the model, Maple (1982) found a significant relationship between social distance and L2 proficiency in his study on a large sample of Spanish learners of English living in the target language culture. Likewise, Hansen (1995) reached the same strong correlation between social distance variables and the degree of accent in the study of 20 German immigrants in the US in terms of their pronunciation skills. Norton Pierce (1995) also emphasized the strength of Schumann's model in the socio-cultural context of language acquisition by pointing out the importance of regular contact between language learners and speakers of the target language for success in L2 acquisition. It seems that this model has some dependable arguments with regard to social distance variables and L2 proficiency in general or in some aspect like pronunciation but this does not seem enough when the amount of supporting evidence is considered. Even Schumann (1986) himself acknowledged the incompleteness of his model.

One of the reasons why there exists limited support in empirical studies for the model is that the concept of acculturation is too complex to be operationally defined as suggested by Saville- Troike (2006). Additionally Freeman and Long (1991) stated that it is not possible to test the model since there exist no reliable and valid measures of social and psychological distance.

The model does not appear efficient enough to describe how social and psychological factors differ from individual to individual. Schumann disregards the significance of personal factors such as age, gender, cognitive factors, educational background, learning styles, family separation, etc. For example there is evidence from some studies that when acculturation starts early especially before primary school, the acculturation process is more unproblematic and smooth (Beiser et al., 1988, as cited in Berry, 1997). This evidence indicates that age has much more effect than culture itself. Furthermore, gender has been found to be an effective variable on acculturation since the status and treatments of females may differ in two cultures (Beiser et al., 1988, as cited in Berry, 1997). Therefore females seem to be more at risk than males for acculturation issues. On the other hand, there are some learners that will be determined to be successful regardless of any conditions surrounding them and those learners that will not succeed no matter how the conditions are favorable for language acquisition. Thus this implies that individual learner differences are more effective in second language acquisition than social conditions.

Much of the criticism focuses on the model's incompleteness in the specification of 
the combinations and levels of social and psychological factors to predict language outcome. It is obvious that various social and psychological factors can be used to explain the differences in L2 acquisition; however, it is unlikely to determine which factor is the most effective or the extent to which one factor contributes to the acquisition. Freeman and Long (1991) also point out that Schumann did not explain how these factors influence the rate of language attainment. Also, second language learners go through different amounts of acculturation (Damen, 1987) because of the dynamic nature of acculturation. The conditions for L2 acquisition will change as the social and psychological distance changes throughout one's life in the target language environment.

It may be concluded that this model serves as a general outline of the effects of social and psychological variables on second language acquisition. The Acculturation Model needs to be clearly classified and the factors affecting it and their relationships need to be precisely determined and measured through some empirical and longitudinal studies. The individual differences of learners in addition to cognitive and instructional factors should also be taken into consideration in the acculturation process.

\section{References}

Berry, J. W. (1997), "Immigration, Acculturation and Adaptation", Applied psychology: An International Review, 46 (1), 5-68.

Brown, H.D. (2007), Principles of Language Learning And Teaching, (5th ed.), Pearson Education, New York.

Cabassa, L. J. (2003), "Measuring Acculturation: Where We Are And Where We Want To Go", Hispanic Journal of Behavioral Sciences, 25, 127-146.

Crozet, C., and Liddicoat, A.J. (2000), “Teaching Culture As An Integrated Part Of Language: Implications For The Aims, Approaches And Pedagogies Of Language Teaching”, In A.J. Liddicoat \& C. Crozet (Eds.), Teaching Languages, Teaching Cultures (pp. 1-18), Melbourne: Applied Linguistics Association of Australia.

Damen, L. (1987), Culture Learning: The Fifth Dimension in the Language Classroom, Addison-Wesley Publishing, U.S.A.

Ellis, R. (1994), The Study Of Second Language Acquisition, OUP, Oxford.

Hansen, D. (1995), “A Study Of Effect Of Acculturation Model On Second Language Acquisition”, In F. Eckman, d. Highland, P. Lee, J. Milcham, and R. Weber (eds.): Second Language Acquisition Theory ad Pedagogy, Manwah, N.J.: Lawrence Erlbaum.

Howell, W. R. and Vetter, J. H. (1976), Language in Behaviour, New York: Human Sciences Press.

Larsen-Freeman, D. and Long, M. H. (1991), An Introduction to Second Language Acquisition Research, New York: Longman. 
Maple, R. (1982), Social Distance and Acquisition of English as a Second Language Acquisition: A Study Of Spanish-Speaking Adult Learners, Unpublished PhD dissertation, University of Texas at Austin.

Mistrík, E., Haapanen, S., Heikkinen, H., Jazudek, R., and Ondrušková, N. (1999), Kultúra a multikultúrnavýchova/Culture and multicultural Education, Bratislava: IRIS.

Navas, M., Garcia, M. C., Sanchaz, J., Rojas, A., Pumares, P., and Fernandez, J. S. (2005), "Relative Acculturation Extended Model (RAEM): New Contributions With Regard To The Study Of Acculturation”, International Journal of Intercultural relation, 29, 21- 37 .

Norton Pierce, B. (1995), "Social Identity, Investment and Language Learning", TESOL Quarterly, 29(1), 9-31.

Peck, D. (1998), Teaching Culture: Beyond Language, Yale: New Haven Teachers Institute.

Samovar L. A., Porter E., and Jain N. C., (1981), Understanding Intercultural Communication, Belmont, CA, Wandsworth Inc.

Saville-Troike, M. (2006), Introducing Second Language Acquisition, Cambridge: Cambridge University Press.

Schumann, J. H. (1978), The Pidgination Process: A Model for Second Language Acquisition, Rowley, MA: Newbury House.

Schumann, J. H. (1986), "Research of the Acculturation Model for Second Language Acquisition”, Journal of Multilingual and Multicultural Development. 